\title{
THE RIGHT OF SUIT UNDER THE CONTRACT OF AFFREIGHTMENT
}

\author{
Haji Hairuddin Haji Megat Latif ${ }^{1}$
}

\begin{abstract}
In carriage of goods by sea, usually parties involved in the transaction are composed of a seller of goods (exporter), buyer (importer), forwarding agent, ship owner, carrier and port authority. When the contract of carriage is entered, basically it involves the shipper of goods (not necessarily the seller of goods) and the ship owner. The question normally arises are as follows: Who is the right or proper person to bring action should a breach of contract occur?; If the goods damage or loss in transit, who should claim damages for the loss or damage?; What are the laws applicable in Malaysia after 1992?. All these questions become very important due to the changes of law in England in 1992, relating to the right of suit. This paper attempts to answer all the above questions based on The Civil Law Act 1956 (The Malaysian Act), The Bill of Lading Act 1855 (The English Act) and The Carriage of Goods by Sea Act 1992 (The English Act).
\end{abstract}

\section{Introduction}

The English Carriage of Goods Act 1992 was passed to remedy a number of rights of suit problems under the Bills of Lading Act 1855. These problems stem from the provision of section 1 of 1855 Act which effecting a transfer of shipper's rights vis-a-vis the carrier to the consignee of goods or indorsee of the bill of lading to whom property in the goods passed upon or by reason of the consignment or indorsement. Before discussing the relevant provisions of the new 1992 Act, the presenter will firstly discuss the problems arising out of the section 1 of the 1855 Act and its solutions then followed by discussions of the 1992 Act.

Associate Professor in Law, Diploma (Public Admin.) UiTM, LL.B (Hons.) Malaya, LL.M (International Law) Nottingham, School of Law, College of law, Government and International Studies, Universiti Utara Malaysia. 


\section{The Bills of Lading Act 1855}

\section{(1) Section 1 of the 1855 Act}

Section 1 of 1855 Act is not effectively drafted to achieve its purpose, perhaps because the law relating to bills of lading was in its infancy in 1855, or perhaps simply because of inaccuracy on the part of the legislature. ${ }^{2}$ This section was intended to obviate the inconvenience of the decision of Thompson $v$. Dominy ${ }^{3}$ : whereas since Lickbarrow v. Mason ${ }^{4}$ indorsement and delivery of a bill of lading could transfer property in goods, the transfer nevertheless did not acquire a right to sue (nor could he be sued) in his own name. It may be supposed that in 1855 this was relatively recent problem, as before the establishment of regular shipping lines, telegraph, radio and postal services, the buyer would probably have had to call personally at ports of shipment and would himself have been shipper (usually f.o.b). ${ }^{5}$ By 1855 , however, buyers would probably not often have needed to be physically present, so it would frequently have been more convenient, as today, for sellers to undertake shipment. It may be that the purpose of the 1855 legislation was to cope with the change of practice and therefore to transfer contractual rights and obligations to buyer on a fairly general basis, at any rate where the transaction was straightforward sale and not, for example, indorsement by way of a pledge to a bank. ${ }^{6}$

\section{(2) Upon or by Reason of Consignment or Indorsement}

It has been commented that "one can only regret the fact that the Act linked the transfer of contractual rights, and the imposition of liabilities, so closely with the passing of property."

Though "upon" and "by reason of" are presumably alternative, even so property may rarely so pass: often it passes later than consignment or indorsement, and for a different reason. For example, if goods are

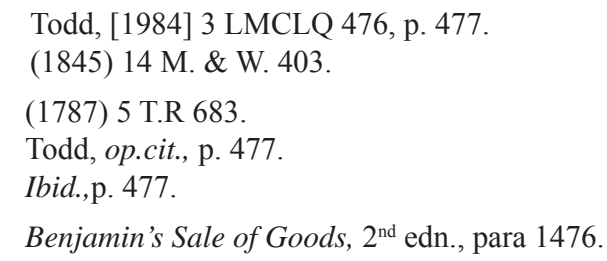


shipped as part of unascertained bulk cargoes ${ }^{8}$ property cannot pass until delivery at the port of discharge.

Sometimes payment may not be made until after indorsement, and if the seller has reserved a right of disposal against payment, property may pass upon and by reason of payment, rather than consignment or indorsement. ${ }^{9}$ And it seems that general property can never pass in favour of a bank as pledge. ${ }^{10}$

It is even possible to argue that property never pass by reason of consignment or indorsement, but depends always on the intention of the parties. ${ }^{11}$

Another difficulty is that the section supposes that contract of carriage is contained in the bill of lading. In fact this is often not the case, and will certainly not be where the shipper has chartered the vessel or part of her, in which case the contract will be constituted by the charter-party, rather than the bill of lading. ${ }^{12}$ Indeed, only "where no prior contract has been made by the owners...can a bill of lading signed by the master be the contract. ${ }^{13}$ So on a literal interpretation, even where there is no time lag, and property therefore passes "upon" consignment or indorsement, it is still arguable that the drafting of the statute is normally inapposite. ${ }^{14}$

Thus Lord Bramwell criticizes that section in general terms in Sewell vs. Burdick, making the point that no contract is contained in the bill of lading, the bill of lading being merely a receipt for goods containing evidence of the terms of the contract of carriage. ${ }^{15}$

In fact, the courts seem to have deviated from as rigid a view as that taken by Lord Bramwell. Lord Atkins, for example, in Hain S.S. Co. v. Tate \& Lyle ${ }^{16}$ thought that the effect of the Act was

\footnotetext{
8 Sale of Goods Act 1979, s. 16.

9 Day, Law of International Trade, 1981, pp. 46-49, 72-77.

0 An interpretation of Sewell v. Burdick, p.105.

Per Lord Bramwell in Sewell v. Burdick, p. 105.

Carver, Carriage by Sea, $13^{\text {th }}$ edn., para 8.

Ibid., para 89.

Todd. op.cit., p. 478.

Per Lord Bramwell in Sewell v. Burdick, p. 105.

(1936) 41 Com. Cas. 350. pp. 356-357.
} 
that a new contract appears to spring up between the carrier and the consignee on the terms of the bill of lading. In the Aliakmon ${ }^{17}$ the Act was applied to transfer rights of suit to the consignee when property passed upon indorsement ${ }^{18}$ and in The Sevonia Team the Act was applied to transfer liabilities when property passed upon consignment. ${ }^{19}$

Thus where there is no time lapse between consignment or indorsement and the passing of property, the courts do not seem to take the point that no contract is originally contained in the bill of lading. ${ }^{20}$ It may be suggested, therefore, that the phrase about the contract being contained in the bill of lading refers only to the statutorily implied contract, leading to the result that actually obtained in Leduc v. Ward ${ }^{21}$ : the statutorily implied relationship between indorsee and carrier is on the basis only of the terms of the bills of lading, and is unaffected by any other terms which may have formed part of the original contract between carrier and shipper. ${ }^{22}$

Even though Lord Bramwell's views would not appear to have been wholly accepted by the courts, a narrow view has still been argued where there is a time lag between consignment and indorsement. ${ }^{23}$ Such a view is adopted, for example by Scrutton where he says:

"If the property in goods passes other than upon or by reason of the consignment or indorsement, the right of suit do not pass to the receiver." 24

Although this view is slightly wider than Lord Bramwell, yet it is still a narrow and liberal interpretation and, if correct, then the Act can hardly work where there is a time lapse, it being difficult to understand of situations where property passes by reason of consignment or indorsement, but where there also a reason for a

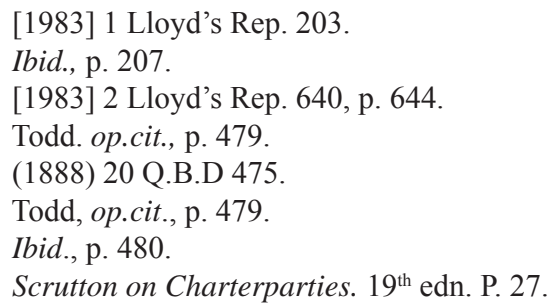


time lapse. ${ }^{25}$ Consequently the likely intention of the legislature is largely defeated. ${ }^{26}$

On the other hand, Carver argues that the section cannot be construed literally, precisely because Lord Bramwell's remarks, which are ironically relied upon by Scrutton to reach a contradictory conclusion, lead to an absurdity. ${ }^{27}$ On Carver's view that section operates whenever property passes to the consignee or indorsee under a contract under which the goods are consigned or in pursuance of which the bill of lading is indorsed. ${ }^{28}$ The fact that the property might pass later than consignment or indorsement is on this view irrelevant, so long as property eventually passes to the consignee. ${ }^{29}$ If correct, this view allows the section to operate to transfer rights and liabilities in practically any c.i.f or f.o.b contract at any rate once the goods are ascertained, enabling to pass. ${ }^{30}$ Todd appears to have preferred this view despite its not being literal interpretation of the section. ${ }^{31}$

More recently, however, Carver's wider view was preferred by the Court of Appeal in The San Nicholas, ${ }^{32}$ referred to by Lloyd J., in The Sevonia Team $^{33}$ and a wider view at any rate then Scrutton's was preferred in The Elaf. ${ }^{34}$ In neither case, however, did the point arise directly. ${ }^{35}$ In San Nicholas, Lord Denning M.R., based his decision on the nature of the particular bill of lading in the case, and in any event took only a prima facie view, ${ }^{36}$ while Roskill L.J., also refused to express a final view in an interlocutory appeal. ${ }^{37}$ In The Elafi the consignee was also able to sue in tort, so statements on transfer of contractual rights were strictly obiter.

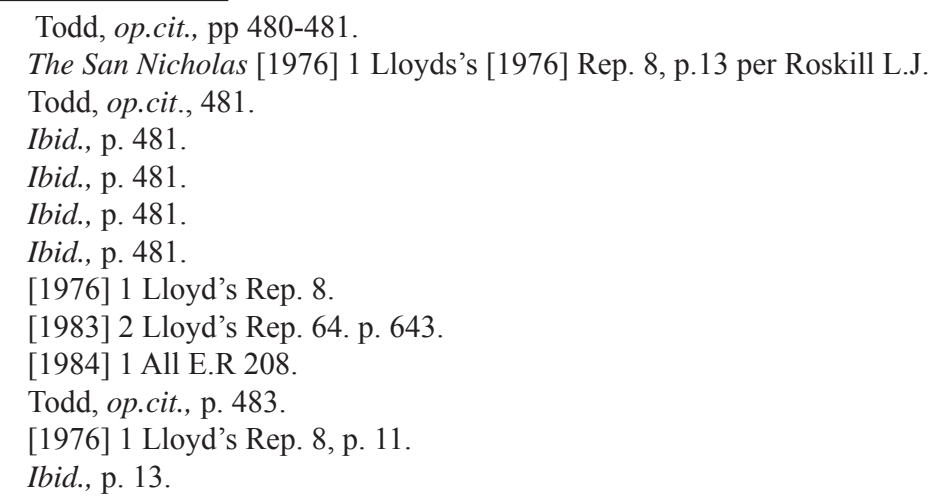


Another situation, where the Act 1855 cannot apply is when a bank holds a bill of lading as a pledge. The result of the court's decision in Sewell v.Burdick ${ }^{38}$ was that a bank in such a position was not liable by virtue of the operation of Section 1 to the shipowner for freight, the principle in the case being that general property in goods did not pass to the pledgee. Nevertheless. "if the pledgee realizes the security general property will pass, but it could hardly be said to pass upon or by reason of consignment or indorsement even the view taken by Lloyd J." ${ }^{\prime 39}$

Further, where parts of unascertained bulk cargoes are involved. Invariably in this situation property will not pass by virtue of a bill of lading at all. Further problems could arise if the goods are lost after indorsement but before they are ascertained, at least on the assumption that it is impossible to pass property in goods that no longer exist. ${ }^{40}$

A final situation in which difficulties may arise is where property passes before, or independently of, consignment or indorsement. This problem arose in The Delfini, ${ }^{41}$ where the relevant indorsement took place eleven days after the completion of delivery and were in no way instrumental in transferring title.

\section{(3) Alternatives to Section 1}

\section{(a) Implied Contracts}

This approach is based on the argument that even though the indorsee is not party to the original contract of carriage, nevertheless should he present the bill of lading to the carrier and take delivery of his portion of the cargo on payment of the appropriate freight, a contract will be implied on the terms set out in the bill of lading ${ }^{42}$

The implied contract on the terms of the relevant transport document, is formed when the carrier delivers the goods in exchange for the

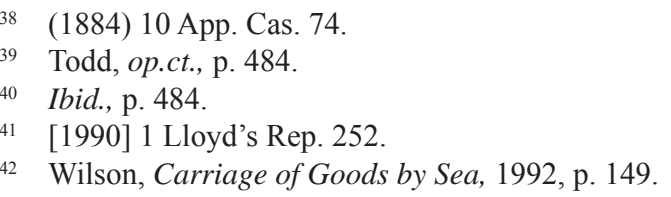


document, be it a bill of lading, ${ }^{43}$ or a delivery order ${ }^{44}$ or even a guarantee that the bill of lading will be presented in due course. ${ }^{45}$

This method was adopted in Brandt v. Liverpool. ${ }^{46}$ In that case goods (zinc ashes) were shipped damaged, but the shipowner nevertheless issued a bill of lading stating that they were shipped in apparent good order and condition. Subsequently, the cargo had to be unloaded and reconditioned, at a cost of $£ 748$, and re-shipped on another vessel, being forwarded late to its destination.

The bill of lading was indorsed in favour of the plaintiff pledgees (a bank) who advanced money on it in good faith. When the second vessel arrived at its destination, the indorsees presented the bill of lading, paid the freight and (under protest) the sum of $£ 748$, which the shipowner demanded, and took delivery of the cargo.

The indorsee bank then sued the shipowner for damages due to delay (the general value of the cargo having fallen) and for repayment of the $£ 748$. As pledgee they had no action based on the 1855 Act. The court decided in favour of the indorsee bank and held that by the acts of presenting the bill of lading, payment of the freight and delivery of the cargo a contract was implied between the indorsee and the shipowner on the terms of the bill of lading.

The principle stated by the court is subsequently known as Brandt $v$. Liverpool doctrine. The doctrine does not depend on the transfer of bill of lading, or on the passing of property. Its operation, however, depends to some extent on whether the facts support the implication of a new contract, but where they do, many of the difficulties of the 1855 Act are avoided. ${ }^{47}$ The implication is that where a bill of lading (or ship delivery order) is presented and the goods are delivered, the delivery is on the terms of the bills of lading (or ship delivery).$^{48} \mathrm{It}$ should also be remembered that this implication does not depend on the passing of general or special property, hence the difficulties of the 1855 Act do not apply. ${ }^{49}$

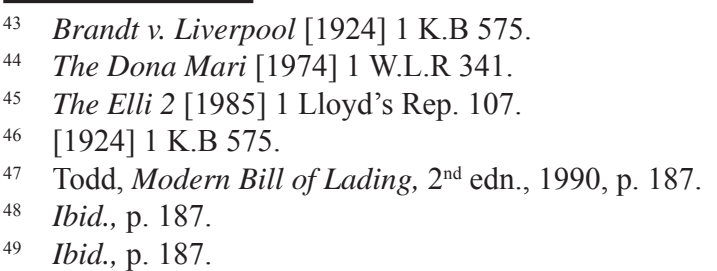


Among the difficulties in the operation of the 1855 Act are its dependence on the passing of property, and its limitation to transfer of bills of lading. Other documents such as delivery orders, are not covered. The effect of this limitation is that the Act rarely operates on sales of parts of undivided bulk consignments..$^{50}$ Brandt v. Liverpool is not subject to any of these limitations. ${ }^{51}$

The doctrine was applied in The Dona Mari ${ }^{52}$ where a cargo of tapioca chips had been shipped in bulk under two bills of lading which were issued to the consignee. Both bills were clean despite the fact that the mate's receipts recorded that the tapioca was damp on shipment. The consignee then indorsed one of the bills to the plaintiff and handed it over together with a ship's delivery order for part of the reminder of the cargo. After the plaintiff had taken delivery of his share of the cargo against the production of the documents, he subsequently sued the carrier for cargo damage caused by the moisture, seeking to rely on the estoppels created by the clean bills. Even though he had no rights under the original contract of carriage, since property in the goods had been transferred by indorsement of the bill, the trial judge held that he could recover. ${ }^{53}$

The Brandt v. Liverpool doctrine had been partly blocked by Bingham L.J in The Aramis. ${ }^{54}$ In that case there was a complete failure by the carrier to deliver any cargo. Here a quantity of goods covered by several bill of lading had been shipped in bulk but, by time the final bill was presented by its holder at the port of discharge, the supply of cargo had been exhausted. The court of Appeal held that no contractual relationship between a shipowner and the holder of bill of lading could be inferred merely from the presentation of the bill by the holder to the shipowner, followed by the delivery, by the shipowner to the holder, of parts of the goods covered by the bill.

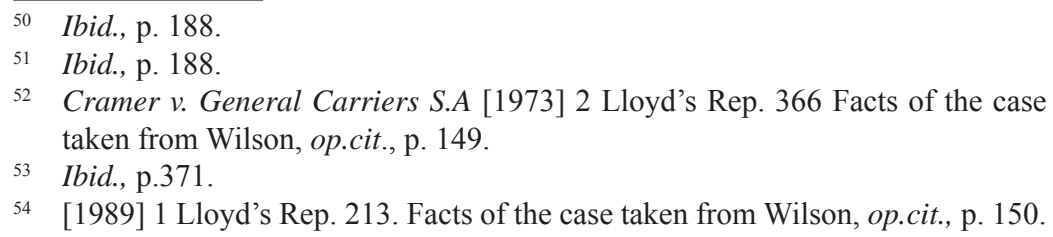


But the decision has been criticized by a number of commentators on the grounds that the court were too rigid in applying the contractual rules on offer, acceptance, consensus ad idem and considerations..$^{55}$

Now, however, the Captain Gregos (No.2) ${ }^{56}$ suggest a new willingness to find a way through. ${ }^{57}$ In that case the Court of Appeal held that on the facts and the evidence a contract was to be implied between $\mathrm{BP}$ and the shipowners to give business reality to the transaction between them. ${ }^{58}$ However, the limitations of this doctrine are still unclear. ${ }^{59}$

To make the doctrine operates, however, "it is essential that delivery is taken against payment of freight or other outstanding charges, since the latter provide the consideration necessary to make the implied contract enforceable." ${ }^{60}$ Presumably in cases where the freight is pre-paid and there are no other charges outstanding, the indorsee will be unable to invoke this principle. ${ }^{61}$ The payment of freight (or other charges) constitutes the consideration for the implied contract, moving from the receiver of the cargo. The consideration moving from the carrier is delivery of the cargo, on the terms of the bill of lading. ${ }^{62}$

Although in all cases in which the doctrine has been successfully invoked by a receiver of cargo, he has paid freight or demurrage, in principle, there should be no need to find financial consideration, so long as some consideration can be found. May be presentation of the bill of lading is sufficient consideration for the new contract. ${ }^{63}$

\footnotetext{
55 Clarke, [1991] 1 LMCLQ 5, p. 6-7. See also Treitel, [1989] LMCLQ 162, p. 170.

56 [1990] 2 Lloyd's Rep. 395. Facts of the case taken from Clarke, op.cit., p. 7

57 Clarke, op.cit., p. 6

8 [1990] 2 Lloyd's Rep. 395, see pp.402-403 per Bingham L.J.

59 Wilson, op.cit., p. 150. See also Todd, Modern Bill of Lading, 1990, p. 190.

Wilson, op.cit., p. 150

Ibid., p. 150.

Todd, Modern Bill of Lading., 1990, pp. 190-191.

Ibid., p. 191.
} 


\section{(b) Suing in Tort}

In the Irene's Success ${ }^{64}$ it was held, that where goods are damaged in course of transit by the negligence of the shipowner, the buyer under a c.i.f contract can sue the shipowner in tort. In that case Lloyd J. declined to follow The Wear Breeze. ${ }^{65}$

But in The Aliakmon ${ }^{66}$ the court rejected the more liberal approach of the Irene's Success. In that case it was a consignment of still coils shipped from Korea to England under a c \& f contract. The contract was subsequently varied, so that the property in the goods remained in the seller until after the goods has been discharged. This fact meant that the buyer could sue shipowner in contract for the damage occurred during the voyage due to the negligence stowage. The property in the goods had not passed to the buyer upon or by reason of the endorsement of the bill of lading. So section 1 of the Bill of Lading Act did not help him. The buyer then tried to sue in the tort of negligence. The court rejected this claim on the ground that he was not the owner of the steel at the time the damage was inflicted. Lord Brandon stated that the decision in The Wear Breeze "was good law at the time it was decided and remains good law today." ${ }^{\circ 67}$

Four reason can be discerned in the decision of the House of Lords. ${ }^{68}$ First, there was the same long line of authority going back to the Simpson v. Thomson ${ }^{69}$ to which Roskill J. had referred in the Wear Breeze. But none of these cases in the long line of authority, save only in the Wear Breeze, concerned a buyer under c.i.f contract. ${ }^{70}$

The second reason given by the House of Lords was the familiar floodgates argument, otherwise known as dreaded spectre. ${ }^{71}$

The third reason is that it would not seem right that the consignee, by suing in tort, should deprive the shipowner of the protection

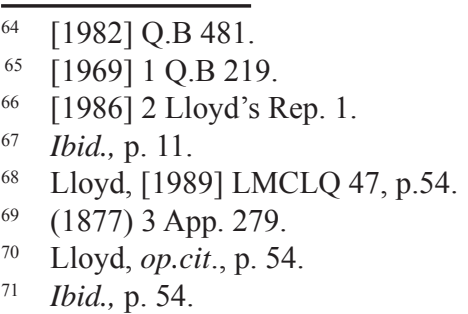


afforded to him by his bill of lading and in particular, of course, any defence he might have under the Hague Rules. ${ }^{72}$

The fourth reason is that the facts of the Aliakmon were special, since, by an amendment to the contract, the passing of property was postponed until after the goods had been discharged. ${ }^{73}$

But, all these reasons have been strongly criticized by Lloyd in this article. ${ }^{74}$ The presenter is, however, of the view that actions in tort should be allowed subject to certain restrictions discussed earlier on. The reason being that, first actions in tort in respect of the carriage of goods by sea have always been possible in the days of the law as we know it now. ${ }^{75}$ The first editions of both Carver and Scrutton dated 1855 and 1886 respectively and of course well before a whisper of Donoghue v. Stevenson both make it clear that carriers may be liable in tort as well as in contract, and subsequent edition have said the same in very similar wording, though with little explanation. ${ }^{76}$ Secondly, a number of leading cases in Australia, New Zealand and the United Kingdom have extended the possibility of negligence actions, especially in respect of purely financial loss. ${ }^{77}$ Obvious examples are the Caltex Case $^{78}$. Thirdly, to disallow such actions or even to suggest doing so, however, would be to go against much of the law of bailment: or in a more modern context against the principle that persons owe a duty not willfully or negligently to harm the person or property of others. ${ }^{79}$ Finally Robert Goff L.J's view of limiting the scope of the shipowner's duty in tort rather than denying its existence is, however, most persuasive. ${ }^{80}$ With respect, the writer adds, not only persuasive but more just and equitable to the innocent injured buyer.

\footnotetext{
Ibid., p. 55.

Ibid., p. 55.

Ibid., especially pp. 54-55.

Reynolds, [1986] LMCLQ 97, p. 97.

Ibid., p. 97.

Ibid., p. 97.

(1976) 136 C.L.R 529.

Reynolds, op.cit., p. 105.

Davies, op.cit., p. 2.
} 


\section{(c) Legal Assignment}

Legal assignment may be done in accordance to section 136(1) of the Law of Property Act 1925 which requires the assignment to be absolute, by writing under the hand of the assignor, and that written notice be given to the debtor. ${ }^{81}$ Legal assignments however, suffer from a fundamental defect in a carriage cases since in addition to the other documents the buyer receives, he needs a written assignment of the carriage rights execute by the seller. ${ }^{82}$ Thus, the buyer has to rely on his seller, who may or may not choose to co-operate in assigning his rights. Apart from that it is thought that many foreign sellers will be unwilling to change their standard sales term simply to accommodate a defect in English law. ${ }^{83}$ Furthermore under section 136, notice has to be given to the carrier on each assignment, meaning in a chain of sales that a separate notice is required for each sale. ${ }^{84}$ The final buyer may in the end have little idea either who the original assignor was or what rights have been assigned..$^{85}$

\section{The English Carriage of Goods Act 1992}

\section{(1) Section 2 of the 1992 Act}

The 1992 Act was passed following the recommendations of the Commission Report on the Rights of Suit in respect of Carriage of Goods by Sea.

The 1992 Act solved the problems under 1855 Act in three main ways. ${ }^{86}$ First, by removing the link between the acquisition of the contractual rights and the transfer of property which existed in the 1855 Act. Secondly, by including sea way bills and ship's delivery orders within its ambit. Finally, by allowing regulations to be made so as to apply the provisions of the Act to paperless transactions involving electronic data interchange.

81 See The Kelo [1985] 2 Lloyd's Rep. 85.

82 Curwen, [1992] JBL 245, p. 248.

83 Law Com. No. 196: Scot. Law Com. No. 130 (1991), p. 9.

84 Ibid., p. 9

85 Ibid., p. 9 .

86 James Cooper, Annotations of the Carriage of Goods by Sea Act 1992. Lord Chancellor Department. 
The Act is expressed to apply to bills of lading, sea waybills and ship's delivery orders. ${ }^{87}$ These terms are defined, but the definitions are unlikely to cause many surprises. It should be noted, however, that a non-negotiable bill of lading (for example one which is consigned without the words 'to order' will, for the purposes of the Act, be treated as a sea waybill since it is non-negotiable document and is therefore more akin to a sea waybill than the traditional bill of lading. ${ }^{88} \mathrm{~A}$ 'received for shipment' bill of lading is also included in the bill of lading definition so that, in appropriate cases, multimodal transport documents will be capable of falling within the scope of the Act. ${ }^{89}$ In relation to delivery orders, the Act is only concerned with those containing or giving rise to undertakings by the carrier to deliver the goods. It is not concerned with merchants' delivery orders unless the carrier has 'attorned' and thereby imposed on himself an obligation to deliver. ${ }^{90}$ The decision to extend the legislation to waybills and ship's delivery orders is an extremely important one which may well lead to increased use of such documents in place of bills of lading in a number of trades. ${ }^{91}$

Section 2(1) is concerned with the transfer of rights under the above documents. It provides that (i) a person who becomes the lawful holder of the bill of lading and (ii) a person (other than the shipper) to whom delivery of goods is to be made under a sea waybill or ship's delivery order, 'shall (by virtue of becoming the holder of the bill or as the case may be the person to whom delivery is to be made) have transferred to and vested in him all rights of suit under the contract of carriage as if he had been a party to that contract'. ${ }^{92}$

In the case of bill of lading the section finally breaks the links between the transfer of contractual rights and the acquisition of property "upon or by reason of" consignment or indorsement. ${ }^{93}$

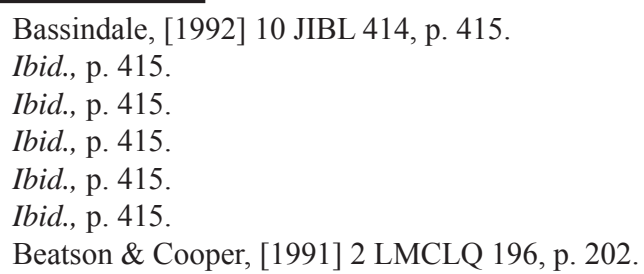


Lawful possession of the bill rather than the acquisition of property or being on risk, becomes the touchstone of the transfer of right of suit. ${ }^{94}$

It will be seen that the offending provision of the original Bills of Lading Act 1855, under which the transfer of right could only occur if property passed 'upon or by reason of the consignment or endorsement' has gone in its entirety. ${ }^{95}$ This provision therefore, at one stroke removes many of the problems which have arisen in the past and, in particular, solves the problems created for bank by the decision in Sewell v. Burdick. ${ }^{96}$

In the case of sea waybills, the person entitled to sue is stated to be the person who, without being an original party of the contract of carriage, is entitled to delivery. ${ }^{971}$ It should be noted that right are not given to the named consignee simpliciter. Since a sea waybill is not a transferable document of title, the shipper will (unless he has made contractual provision otherwise) retain rights of disposal over the goods until the time of delivery. ${ }^{982}$ If right were given to the named consignee as from the time of consignment, this would prevent the shipper from exercising his rights of disposal in favour of new consignee. ${ }^{993}$ Thus, in the case of sea waybill, section 2 (1) (b) gives rights to the person entitled to delivery, which means the named consignee or such other person to whom the carrier is directed to deliver.

In some sense, this provision on its own would be almost too far reaching. It would have allowed parties to go on transferring a bill of lading long after delivery of the goods, so that transferees would acquire rights against the carrier in respect of goods over which they had never had an interest. ${ }^{1004}$ This would have been tantamount to trading in litigation claims, which was felt to be undesirable. ${ }^{1015}$ Section 2(2), therefore, provides that where the bill of lading

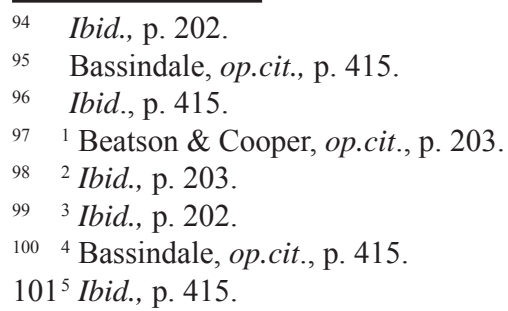


passes to a transferee after discharge, he will acquire no right unless he becomes the holder pursuant to a pre-existing contractual arrangement (for example a prior sale contract).

Given that section 2(1) speaks of the transfer of rights under the contract of carriage, section 2(3) ensure that the right of suit of the person entitled to delivery under the terms of ship's delivery order are confined to the goods covered by the order and do not extend to the other goods covered by the underlying contract of carriage. ${ }^{1026}$

In some cases, the party who acquires the ultimate right of suit under these new provision will not be the person who has actually suffered the loss. ${ }^{1037}$ Section 2(4) therefore provides that, in such cases, he will be able to exercise his newly acquired rights of suit for the benefit of the person who has. The Act does not, however, address the problem of what is to happen if the holder is not prepared to do so, and this will presumably have to be sorted out in the underlying sale contracts, or on an ad hoc basis when problems arise. ${ }^{1048}$

Section 2(5) (a) provides that the bill of lading shipper loses rights of suit when someone else (such as a subsequent indorsee of the bill of lading) acquires them. This follows the position under the bill of lading Act 1855. Where sellers remain on risk beyond the normal time in documentary sales, they can make special contract to protect themselves. ${ }^{1059}$ Furthermore, the shipper can seek a reindorsement of the bill of lading in those cases where he needs rights of suit he will in such cases, be able to sue qua lawful holder of the bill of lading. ${ }^{10610}$

Section 2(5) (b) provides that those intermediately entitled to delivery under bills of lading, sea waybills and ship's delivery orders lose rights of suit when others acquired them. Again, this follow, in the case of bills of lading, the position under the 1855 Act, whereby previous holders of bills of lading lost their rights of suit when there were transferred in the way stipulated by section 1 of the

\footnotetext{
$102 \quad{ }^{6}$ Beatson \& Cooper, op.cit., p. 204.

${ }_{103}{ }^{7}$ Bassindale, op.cit., p. 416.

1048 Ibid., p. 416.

1059 James Cooper, op.cit., p. 50-6.

${ }_{106}{ }^{10}$ Ibid., p. 50-6.
} 
Act. ${ }^{10711}$ The intermediate seller in chain who remains on risk after indorsement can arrange an assignment of the buyer's rights against the carrier. ${ }^{10812}$

The Act does not attempt to change the law relating to claims in tort; no does it seek to regulate charter party contract. The law relating to the interrelation between bills of lading and charter parties therefore remains unaffected. ${ }^{10913}$ One consequence of extending the cargo receivers' right to sue, but not restricting the possibility of claims in tort under the charter party may be to increase the risk of more than one claim being brought against the carrier in respect of the same loss. ${ }^{11014}$ This was a point which the Commission did consider but they conclude that this was a problem which had not caused difficulty under the old law (where dual claims were also permissible) and that the courts would not allow the carrier to be liable twice over. Accordingly they concluded that the problem was apparent than real. ${ }^{11115}$

The other point should be noted concerning charter party is, where a bill of lading is issued to the shipper and is thence indorsed to the charterer/indorsee's, rights against the shipowner stem from the charter party or the bill of lading? ${ }^{11216}$ The answer is not addressed explicitly in the new Act, nor was it under the Bills of Lading Act 1855. ${ }^{11317}$

Finally, what is the position where a person who is entitled to delivery of the bill of lading never receives it (say, because it is lost) or receives it only after expiry of one-year limitation period in the Hague-Visby Rules? ${ }^{11418}$ This question remains a matter which may require resolution from the courts. In these circumstances, recovery may be denied under the Act. ${ }^{1519}$ Recourse to an implied

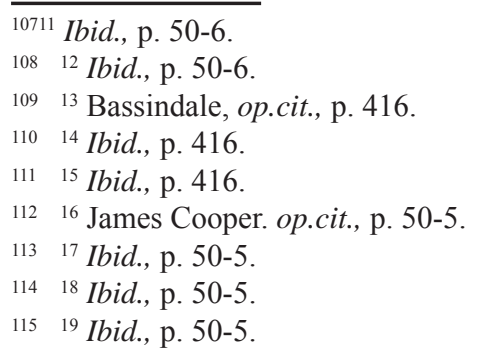


contract between the buyer and the carrier on the terms of the bill of lading, a so-called Brandt v. Liverpool contract, remains one way of circumventing problems which are not solved by the Act. ${ }^{11620}$

Even though, there are a number of questions have still not been solved by the 1992 Act, yet the new English Act is much better than the 1855 Act. In the words of one commentator: ${ }^{11721}$

"We believe that the end result will be an all round improvement. It will be good for the trades and their insurers, who will be able to assert rights against sea carriers without any technical restrictions such as showing that property passed in a particular way or that they were on risk. It will be good for liner shipowners, by reason of the fact that the reform puts sea waybills and E.D.I on a statutory footing. Indeed, it will be to the benefit of all sea carriers... it reduces the need for cargo interests to seek redress by action in tort or bailment, with their potentially much wider ambit... the new reform, in extending the contractual regime, should correspondingly reduce the need for parties to rely on tort, bailment and the Brandt v. Liverpool device. It is thus to be welcomed in the interest of commercial certainty."

\section{Conclusion}

By virtue of section 5 of Civil Law Act 1956, any statute relating to carriage of goods by sea passed in England after 7 April 1956 is inapplicable in Malaysia. Thus, it is argued that The English Carriage of Goods Act 1992 is not enforceable in Malaysia. Hence, after 19 September 1992, Malaysia still applies the Bill of Lading Act 1855. It is, therefore, suggested that any amendment to the law of carriage of goods by sea should take into account the aspect relating to the right to sue under the contract of affreightment.

\footnotetext{
$116 \quad{ }^{20}$ Ibid., p. 50-5.

$117 \quad 21$ Beatson \& Cooper, op.cit., p. 208.
} 


\section{Bibliography}

Bassindale, J., "Title to sue under bills of lading: The Carriage of Goods by Sea Act 1992" [1992] 10 JIBL 414.

Beatson, J. \& Cooper, J.J, "Rights of suit in respect of carriage of goods by sea" [1991] 2 LMCLQ 196.

Clarke, "The consignee rights of action against the carrier of goods by sea, The Captain Gregos (no. 2)" [1991] 1 LMCLQ 5.

Colinvaux, R. (1982). Carver's Carriage by Sea (13 ${ }^{\text {th }}$ edn.). London: Steven \& Sons.

Cooper, J., "Annotations of the Carriage of Goods by Sea Act 1992". Lord Chancellor Department. England.

Curwen, "The problem of transferring carriage rights: An equitable solution" [1992] JBL 245, p. 248.

Day, D.M. (1981). Law of International Trade. London: Butterworth \& Co. (Publisher) Ltd.

Guest, A.G. (1981). Benjamin's Sale of Goods (2 ${ }^{\text {nd }}$ edn.). London: Sweet and Maxwell.

Lloyd, "The bill of lading: Do we really need it?" [1989] LMCLQ 47.

Reynolds, "The significance of tort in claims in respect of carriage by sea" [1986] LMCLQ 97.

Sale of Goods Act 1979.

Scrutton, T. E., Macotta, A. A., Mustill, M. J. and Boyd, S. C. (1984). Scrutton on Charterparties and Bills of Lading (19 $9^{\text {th }}$ edn.). London: Sweet \& Maxwell.

Todd, P.N., "Contract with consignees and indorsees" [1984] 3 LMCLQ 476. 
Todd, P.N. (1990). Modern Bill of Lading ( $2^{\text {nd }}$ edn.). London: Butterworths \& Co.

Wilson, J.F. (1992). Carriage of Goods by Sea. London: Pitman Publishing. 